\title{
Potoczność w tekstach prasowych
}

\author{
Maria Wojtak \\ UMSC Lublin \\ maria.wojtak@poczta.umcs.lublin.pl
}

\section{Streszczenie}

W artykule opartym na materiale z prasy wyspecjalizowanej autorka porusza nastepujace zagadnienia: dlaczego tak bardzo atrakcyjny jest dla dziennikarzy styl potoczny, jakie składniki i cechy tej odmiany traktowane sa jako szczególnie użyteczne, jakie sa skutki częstego użycia form potocznych dla procesów przeobrażania stylu publicystycznego $i$ wybranych gatunków prasowych. Potoczność rozpatrywana na płaszczyźnie tekstu zyskuje na komunikacyjnej atrakcyjności dlatego, ̇̇e pozwala nadawać wypowiedziom znamiona komunikatów skierowanych, nastawionych na kontakt $z$ drugim człowiekiem, umożliwia ucieczke od abstrakcji $w$ strone mówienia (czy raczej pisania) konkretnego, bliskiego codziennemu doświadczeniu, obrazowego i zaangażowanego. Dzięki stosownym zabiegom stylizacyjnym publicyści buduja z odbiorca wspólny świat i ksztattuja określona wizję tego świata: (1) z punktu widzenia odbiorcy - z uwzględnieniem jego potocznych wyobrażeń i doświadczeń; (2) zgodnie z oczekiwaniami odbiorcy, a więc przystepnie, plastycznie i sugestywnie; (3) z (fingowanym) udziatem odbiorcy; (4) za pomoca środków językowych znanych odbiorcy (potocznych) lub środków wykreowanych przy użciu technik stylizatorskich typowych dla wypowiedzi potocznych.

Stowa kluczowe: dziennikarstwo, komunikacja, prasa, prasa specjalistyczna, styl potoczny

Abstract

Colloquialisms in Press Texts

In the article which is based on specialized press material, the author raises the following issues: why is the colloquial style so attractive for journalists? What features and factors of this variety are treated as particularly useful? What are the results of the frequent use of colloquial forms for the processes of transforming the journalistic style and selected press genres? Colloquialisms considered at the textual level gain the communicative attractiveness 
because they allow utterances to acquire the status of targeted messages, aimed at seeking contact with a fellow human being, and because they facilitate the escape from abstraction towards concrete speaking (or rather writing), close to everyday experience, imagistic and involved. Thanks to appropriate stylization techniques, journalists construe the world in common with the audience and shape a specific vision of this world: 1/ from the point of view of the audience, taking into account their colloquial images and experiences; $2 /$ in accordance with the audience expectations, i.e. simply, visually and suggestively; 3/ with the (fake) participation of the audience; 4/ through linguistic means known to the audience (colloquial) or the means created with the stylization techniques typical of colloquial utterances.

Keywords: journalism, communication, press, specialized press, colloquial style

\section{Wstęp}

W przedstawianym artykule nie zamierzam snuć refleksji na temat istoty potoczności, statusu potocznej odmiany języka czy zbioru jej wyróżników. Przyjmuję, że polszczyzna potoczna to taka stylistyczna odmiana języka, która jest wyzyskiwana przede wszystkim w codziennych kontaktach komunikacyjnych. Status stylu przypisuje się temu wariantowi języka ze względu na zastosowania komunikacyjne, a także zbiór cech i językowych wykładników przekazujących określoną wizję świata czy też koncepcję doświadczania świata (zob. Bartmiński 1992: 38 i in.). Wśród wyróżników polszczyzny potocznej umieścić trzeba prymarną mówioność, powszechność zasięgu, spontaniczność, niespecjalistyczny charakter wysłowienia, familiarność i ekspresywność (zob. Lubaś 1983: 86; Anusiewicz 1992: 11-12).

Polszczyzna potoczna, co zgodnie uwypuklają badacze (zob. Skawiński 1992: 82; Ożóg 2001: 48-49), była do niedawna niedoceniana zarówno jako obiekt badań, jak i środek komunikacji. Sytuacja się zmieniła po roku 1989 i obecnie postrzega się tę odmianę jako ekspansywną, wręcz modną (Skawiński 1992: 83, 86; Kita, 1993: 37; Dunaj, Przybylska, Sikora 1999: 229, 246; Lubaś 2000b: 162; Ożóg 2001: 69-70; Kamińska-Szmaj 2001: 59-61). Zwiększył się zakres użycia języka potocznego w komunikacji oficjalnej: w wystąpieniach polityków, w mediach, a zwłaszcza w reklamie (por. Kita 1993: 34-38; Ożóg, 2001: 48-72 i in.).

Dostrzegając ekspansję języka potocznego w tekstach prasowych, językoznawcy przedstawili: obecną w tych tekstach leksykę potoczną (Lubaś 2000a: 83-95), potoczną stylizację w tytułach (Ożóg, 2001: 67; Kamińska-Szmaj 2001: 59-61) i podstawowe funkcje form potocznych. Jako środek perswazji potocyzmy przełamują dystans między nadawcą a 
odbiorcą, służą kreowaniu wizerunku nadawcy i przeciwstawianiu się oficjalnej sztampie (por. Lubaś 2000a: 84-85, 89). Stają się ponadto zaproszeniem do gry językowej (zob. Skawiński, 1992: 83; Kita, 1993: 34-38; Ożóg, 2001: 67-69; Kamińska-Szmaj 2001: 59-61).

Wstępna analiza licznych wypowiedzi z prasy ogólnej i wyspecjalizowanej pozwala domniemywać, że znacznie szerszy w stosunku do już opisanego jest zakres użycia form potocznych, bardziej zróżnicowana i bogatsza motywacja oraz powiększony zbiór szczegółowych funkcji.

W przedstawianym artykule, opartym na materiale z prasy wyspecjalizowanej, chcę się zastanowić nad następującymi zagadnieniami: dlaczego tak bardzo atrakcyjny jest ostatnio dla dziennikarzy styl potoczny, jakie składniki i cechy tej odmiany traktowane są jako szczególnie użyteczne, jakie są skutki częstego użycia form potocznych dla procesów przeobrażania stylu publicystycznego i wybranych gatunków prasowych.

\section{Dialogowa orientacja stylu publicystycznego}

Naturalnym podłożem stylistycznych interferencji jest otwartość stylu publicystycznego i sygnalizowana już ekspansywność stylu potocznego. Owa ekspansywność ma nie tylko podłoże społeczne i kulturowe. Wiąże się, jak sądzę, z naturą odmian stylowych języka ${ }^{1}$. O ich tożsamości decyduje wiązka cech, spośród których niektóre mają status cech odróżniających, inne zaś mogą się powtarzać w kilku odmianach stylowych języka. W procesach adaptacji stylistycznej może nastąpić zmiana hierarchii cechy, przez jej szczególne uwyraźnienie, a także zmiana typowych wykładników językowych. Styl potoczny podatny jest na interferencje komunikacyjne, gdyż dysponuje środkami o szczególnej plastyczności. Leksyka potoczna, co uwypukla w swych pracach Bartmiński (1992: 41, 2001: 115-116), może z łatwością pełnić rolę eksplikacyjną w stosunku do wyrażeń bardziej wyspecjalizowanych. Tę właściwość leksyki potocznej wyzyskuje się w tekstach prasowych informujących o nowych odkryciach czy wynalazkach bądź rozwiązaniach konstrukcyjnych, o skomplikowanych zagadnieniach gospodarczych, a także innych problemach mało znanych lub nieznanych przeciętnemu czytelnikowi.

Potoczność rozpatrywana na płaszczyźnie tekstu zyskuje na komunikacyjnej atrakcyjności dlatego, że pozwala nadawać wypowiedziom znamiona komunikatów skierowanych, nastawionych na kontakt z drugim człowiekiem, umożliwia ucieczkę od abstrakcji w stronę mówienia (czy raczej pisania) konkretnego, bliskiego codziennemu doświadczeniu, obrazowego i zaangażowanego. 
Zauważmy, że większość wymienionych cech charakteryzowała od dawna także styl publicystyczny ${ }^{2}$. Chcąc odświeżyć typowe dla tego stylu środki stylistyczne, dziennikarze sięgają do stylu potocznego. Styl ten sprzyja jednak także uruchomieniu takich procesów adaptacyjnych, które pozwalają przeobrazić sposób komunikowania się. Obserwuje się bowiem ostatnio $\mathrm{w}$ prasie tendencję do zmiany orientacji komunikacyjnej wypowiedzi. Tekstom informacyjnym zarówno tym, ujętym w formę zapowiedzi, wzmianki czy notatki, jak i takim, które nie spełniają reguł wymienionych wzorców gatunkowych nadaje się kształt wypowiedzi skierowanych. Wspomniana prawidłowość rysuje się szczególnie wyraziście w prasie kobiecej, młodzieżowej i hobbystycznej (zob. Kajtoch 1999: 87-88; Wojtak 2000a: 118-119, 2000b: 235-244).

Większość wypowiedzi informacyjnych publikowanych na łamach owej prasy zawiera różnorodne językowe wykładniki dialogowości zewnętrznej. Wypowiedzi te zyskują status tekstów nastawionych prymarnie na interakcję, bezpośrednią rozmowę - informowanie czy powiadamianie schodzi na dalszy plan. O przejawach tak ujmowanej orientacji dialogowej we wzmiankach i notatkach z prasy hobbystycznej pisałam w oddzielnym studium (Wojtak 2000b: 240), ograniczę się więc w tym miejscu do zwięzłej charakterystyki wybranych przejawów dialogowości w tekstach informacyjnych z prasy kobiecej.

W niektórych typach wypowiedzi orientacja dialogowa jest naturalna i motywowana funkcjonalnie, osobliwe, urozmaicone i zgodne z nową modą komunikacyjną są jedynie jej językowe wykładniki. Uwaga ta odnosi się do wypowiedzi redaktorów tygodników, którzy, wstępnie informując o zawartości numeru, jednocześnie zachęcają sugestywnie do lektury. Aby pokazać typowe dla takich sytuacji strategie komunikacyjne i zbiór stosowanych wtedy środków, odwołajmy się do następującego przykładu³:

(1) PIT 2001 - z nami dasz mu radę Czy wiecie, że najbardziej skomplikowane działanie matematyczne niezbędne do wypełnienia PIT-u to... obliczanie procentów. W tym roku wypełnisz PIT sama, wystarczy ci kalkulator i nasz przewodnik. Krok po kroku wyjaśniamy, co wpisać w kolejne rubryki i to w sposób o wiele bardziej przystępny niż w oficjalnych broszurach z urzędów skarbowych. To trzeba mieć w domu (str. 14). $[\mathrm{P}, 02,5,3]$

Perswazyjną wymowę ma już tytuł, w którym pojawia się czasownik w 2. os. 1. poj. odnoszony do odbiorcy. Publicystka nie stosuje jednej formy gramatycznej identyfikującej odbiorcę. Wprowadza bowiem apele i różnego rodzaju pytania zakodowane w formie TY (2. os. 1. poj. czasowników i formy zaimka ty) lub WY (2. os. 1. mn. czasowników i stosowne formy zaimków). Są to jednak zawsze formy, które zmniejszają lub niwelują dystans między 
nadawcą i odbiorcą. Publicystka kreuje się dzięki takim zabiegom na osobę przyjazną, bliską, taką, która pomoże, wybawi z kłopotów, sugerując zarazem, że rolę kogoś bliskiego pełni także redagowane przez nią pismo. Rzeczywistość w tak wystylizowanym tekście ulega metamorfozie - to, co wydaje się przeszkodą nie do pokonania, zyskuje kształt zjawiska niegroźnego. Aby konceptualizować rzeczywistość we wspomniany sposób, stosuje się w wypowiedziach zapowiadających stały zbiór środków - pytania (często pytania pozorne) i wypowiedzenia stwierdzające $\mathrm{z}$ orzeczeniem w czasie przyszłym, przez co odpowiednie fragmenty wypowiedzi uzyskują funkcję sprawdzającej się bezwzględnie prognozy.

Dialogową orientację mają w prasie kobiecej także teksty nawiązujące do konwencji wzmianki, informujące zwięźle lub bardziej szczegółowo o najważniejszych tendencjach w modzie oraz teksty zawierające różnego rodzaju porady. Zbiór wzmianek pod wspólnym tytułem Sekrety mody (P) składa się z tekstów o ekspresywnych tytułach, pełniących funkcję etykietek stroju i metonimicznych określeń właścicielki ubrania: Wytworna jak królowa; Elegancka, ale niebanalna; Wyrafinowana kokieteria; Subtelna zmystowość; Zamaskowana romantyczka (P, 02, 5, 6-7). W korpusach tekstów zaś znajdujemy sprofilowany opis przedstawianej części garderoby. Jest to opis selektywny i subiektywny zarazem, gdyż pokazuje się w nim wyłącznie atuty stroju. Zyskuje też kształt opisu perswazyjnego, ponieważ zawiera rady dotyczące stosowania określonych składników garderoby. Oto dwa przykłady ilustrujące przedstawiane tendencje:

(2) Patrzcie na mnie Atutem tego kroju są drapowania przy zapięciu. Taką bluzkę noś na przykład z brokatową spódnicą. $[\mathrm{P}, 02,5,7]$

(3) Subtelna zmysłowość Głęboki dekolt bluzki wykończony delikatną falbanką przyciąga wzrok. Dzianina wyeksponuje twoje kształty. [P, 02, 5, 7]

1. Konwencja rozmowy obowiązuje także w bardziej rozbudowanych tekstach informacyjnych, które pełnią funkcję porad. Mogą to być wypowiedzi, w których orientacja dialogowa dominuje we wszystkich segmentach. Apelatywny i prognozujący charakter zyskuje już nagłówek, np.: Wybierz styl dla siebie (tytuł cyklu) i To cię odmłodzi (tytuł konkretnej wypowiedzi prasowej) $[\mathrm{P}, 02,5,8]$. Analogiczny kształt nadano segmentowi zapowiadającemu (jest to odpowiednik lidu w klasycznej informacji):

(4) Odkrywamy przed tobą sekrety młodego wyglądu. Odpowiedni makijaż, fryzura, strój oraz styl życia pomogą ci na wiele lat zachować urodę i dobre samopoczucie. [P, 02, 5, 8] 
Apelatywność, by nie rzec dyrektywność, staje się dominantą komunikacyjną pozostałych fragmentów tekstu, które funkcjonują jako autonomiczne segmenty towarzyszące fotografiom. Oto wybrane przykłady (zawierające ekspresywne wyrazy potoczne: ciuch i leksykę modną: hitowe):

(5) Pamiętaj, jasne kolory ujmują lat. Warto polubić biel, beże, szarości i pastele. Najlepiej, gdy strój skomponujesz w jednej tonacji. [P, 02, 5, 8]

(6) Nie jesteś już nastolatką - wybieraj szlachetne, naturalne tkaniny. Znakomicie wyglądają uszyte z nich stroje o sportowym kroju. Sportowa elegancja to propozycja dla kobiet, które chcą wyglądać młodziej, ale z klasą. $[\mathrm{P}, 02,5,9]$

(7) Staraj się kupować modne ubrania. Nic tak nie postarza, jak ciuchy sprzed kilku sezonów. Oto hitowe zestawienie: kurtka wykończona sztucznym futerkiem noszona do golfa [sic!] robionego grubym ściegiem. $[\mathrm{P}, 02,5,8]$

Dialogowa orientacja tekstu przybiera niejednokrotnie formy typowe dla konwencji epistolarnych, a więc formę rozmowy z oddalonym partnerem. Można wtedy zadawać czytelnikom pytania i natychmiast odpowiadać, posługując się leksyką potoczną lub wyspecjalizowaną i, co ważniejsze, wprowadzając kolokwialne struktury składniowe obok form syntaktycznych typowych dla języka pisanego ${ }^{4}$. Porównajmy:

(8) Lubisz młodzieżowy styl? O ile twoja figura jest bez zarzutu, po 40. wcale nie musisz ubierać się poważnie. Ale powinnaś być wobec siebie krytyczna. Najbezpieczniej, jeśli tylko jeden element stroju będzie awangardowy. [P, 02, 5, 9]

W niektórych typach tekstów informacyjnych mieszają się konwencje mówienia do czytelnika i konwencje mówienia o przedmiocie. Może to oznaczać powrót do informacji klasycznej jedynie w wybranych segmentach tekstu, na przykład w lidzie, czyli pierwszym akapicie, który jest wizytówką tekstu. Krzyżowanie konwencji i eksponowanie kontrastów staje się przyczyną powiększania liczby wzorców alternacyjnych artykułu ${ }^{5}$. Wypowiedź taka, podzielona na autonomiczne segmenty, zyskuje kompozycję typową dla tekstowego kolażu. W poszczególnych fragmentach może dominować stylizacja na tekst wyspecjalizowany i oficjalny (przykład 9) lub tekst potoczny (choć z przewagą środków z rejestru starannego) (przykład 10): 
(9) Bezkofeinowa kawa zawiera przeciwutleniacze, które powstają w procesie jej palenia. Substancje te niszczą zgromadzone $\mathrm{w}$ organizmie wolne rodniki, pochodzące $\mathrm{z}$ zanieczyszczeń powietrza. Przeciwutleniacze walczą też ze zmianami rakowymi, hamują procesy starzenia się, a nawet spowalniają tworzenie się zmarszczek. (...) [P, 02, 5, 27]

(10) Może ci zaszkodzić [kawa - dop. M. W.] tylko wtedy, jeśli przesadzisz z ilością. (...) Bez obaw możesz wypić 2-3 filiżanki w ciągu doby. [P, 02, 5, 27]

Dialogowa orientacja wypowiedzi może w prasie wyspecjalizowanej przyjmować również inny kształt - wynikający z nawiązania do konwencji monologu wypowiedzianego ${ }^{6}$ lub poetyki reportażu z reporterem w roli słuchacza. Bardzo wyraźnie rysuje się zazwyczaj przy tym węzeł dialogowy. Niejednokrotnie wypowiedź jest tak skonstruowana, że pozwala przewidzieć (i wstawić) rzekomą replikę czytelnika. Oto dwa przykłady z magazynu motoryzacyjnego:

(11) Mégan w obecnej formie kończy w tym roku swój rynkowy żywot. Podobny los czeka bazującego na jego płycie podłogowej Scénica. Bez obaw - firma nie zdecydowała się na wycofanie z tak lukratywnego interesu. $[\mathrm{AS}, 02,5,12]$

(12) Właściwie wspólnego mają tylko tyle: oszczędnie obchodzą się z przestrzenią parkingową, paliwem i pieniędzmi swego posiadacza. Mało? My uważamy, że to właśnie najważniejsze cechy. [AS, 02, 5, 20]

\section{Formy potoczne jako chwyty stylizujące w prasie specjalistycznej}

W prasie wyspecjalizowanej obserwuje się tendencję do inkrustowania wypowiedzi informacyjnych ekspresywnymi formami potocznymi czy wręcz kolokwialnymi. Można przypuszczać, że używane w ten sposób formy językowe służą odświeżeniu i stylistycznemu urozmaiceniu tekstu. Są ponadto w pewnym sensie naturalne dla wypowiedzi, które mają informować (na przykład o nowym modelu samochodu czy roweru górskiego) i zarazem oceniać (por. Wojtak, 2000a: 121). Taki sposób kształtowania wypowiedzi wynika ponadto z przyjętego w prasie wyspecjalizowanej modelu komunikacji, modelu, który da się zamknąć w formule: specjaliści (zarazem entuzjaści) mówią do niespecjalistów - zorientowanych jednak w przedmiocie wypowiedzi. W związku z tym dziennikarze nadają swoim wypowiedziom kształt tekstów fachowych i precyzyjnych, ale jednocześnie przystępnych, a więc takich, które odwołują się do potocznych doświadczeń odbiorców (por. Wojtak, 2000a: 124; 2000b: 235). 
Zacznijmy ilustrację powyższych spostrzeżeń od omówienia przykładów, pokazujących formy potoczne (nieliczne w tekście) w roli środków, które czynią wywód bardziej plastycznym i sugestywnym. Przedstawiając nowy model Porsche autor komunikatu kształtuje opis w perspektywie i z punktu widzenia doświadczeń przeciętnego użytkownika samochodu. Posługuje się przy tym ekspresywną leksyką potoczną i leksemami oceniającymi, używanymi w środowisku kierowców. Porównajmy następujące przykłady:

(13) Takie parametry budzą respekt u największych „barowych mistrzów kierownicy”, najlepszych w opowieściach przy piwie, jak to gnali ponad dwieście autostradą i jakie manewry wtedy wyczyniali. Amerykanie mówią: nie gadaj, pokaż! I tu zaczynają się schody. [AS, 02, 6, 10]

(14) Przy profilu 30 bardzo łatwo uszkodzić oponę i felgę. A opon z indeksem prędkości ZR nie naprawia się, więc każdy „kapeć” to wydatek ok. 1500 zł! [AS, 02, 6, 11]

(15) Można wtedy delektować się jazdą i obserwować reakcję kierowców. Kiedy doganiają Porsche, mają dumną minę, że dołożyli „porszawce”. Ale w chwilę później na ich twarzach widać zazdrość. Woleliby pewnie jechać nawet wolniej, ale TAKIM autem. [AS, 02, 6, 11]

Sugestywność wypowiedzi uzyskuje się nie tylko przy pomocy środków standardowych. Odwołując się do potocznych wyobrażeń i skojarzeń, autorzy analizowanych wypowiedzi wprowadzają oryginalne rozwiązania stylistyczne. Porównajmy następujące przykłady:

(16) Trzeba uczciwie przyznać, że ten pudełkowaty samochodzik ma tyle samo wdzięku co skrzynka na listy ale po bliższym poznaniu błyskawicznie ukazuje swój prawdziwy charakter: to ideał codziennego użytkowania. [AS, 02, 5, 20]

(17) Niebieski materiał na fotelach w połączeniu z czerwonym lakierem karoserii powoduje, że aż „okulary bolą”, a taniutki plastik nie tylko obraża poczucie estetyki, ale i drażni powonienie. [AS, 02, 5, 20]

Ten sam mechanizm stylizacyjny pozwala dziennikarzom budować obrazy metaforyczne, wprowadzane w wybranych segmentach wypowiedzi lub organizujące semantykę całego tekstu. Obraz samochodu na przykład jest w pismach poświęconych motoryzacji kształtowany z odwołaniem do konwencji reklamy, a także z uwzględnieniem potocznych wyobrażeń, nierzadko stereotypów. Wśród powtarzających się motywów odnajdujemy postrzeganie 
samochodu jako istoty żywej, człowieka i wreszcie kobiety bądź (rzadziej) mężczyzny. Tekstowe konkretyzacje takich obrazów są urozmaicone. Może się więc pojawić w początkowych partiach tekstu ogólne odniesienie porównawcze, jak w następującym przykładzie:

(18) Jak z piękną kobietą Z Porsche jest tak, jak z piękną kobietą. Wielu mężczyzn o niej marzy, ale jeśli dojdzie do bliskiego kontaktu, wtedy trema daje znać i nie sprawdzają się. Jako kierowcy, oczywiście. [AS, 02, 6, 10]

W innych tekstach poszczególne części samochodu przedstawiane są jako części ciała. Porównajmy dla przykładu:

(19) Nawet po ośmiu latach produkcji Twingo wciąż wygląda tak czarująco, że na „dzień dobry” rano aż chce się pogłaskać jego wyłupiaste „oczy”. [AS, 02, 5, 20]

(20) Miła „buzia”, ciasne ubrania: Daihatsu Cuore jest autem aż o $15 \mathrm{~cm}$ węższym od Twingo! [AS, 02, 5, 22]

(21) Powszechnie wiadomo, że koty nie cierpią wody. A mimo to potrafią godzinami trwać nad stawem albo przy akwarium, by potem błyskawicznym ruchem - mocząc przy tym łape - upolować supersmakowity thusty kąsek. Aby zaś upolować takie grube ryby jak napędzana na cztery koła „trójka” BMW czy Audi A4 quattro, nasz nie do końca jeszcze udomowiony dziki kot, Jaguar, z chęcią zmoczy nie tylko łapę, ale i brzuch na dodatek. [AS, 01, 43, 20]

W dalszej części opisu krzyżują się dwa obrazy: polującego drapieżnika i samochodu. Nie bacząc na ryzykowność takiego konceptu, autor wprowadza ponadto kolejne asocjacje przez odwołanie do obrazu rywalizacji, walki. Porównajmy:

(22) (...) to nie będzie reżyserowana bójka a stylu amerykańskiego wrestlingu ani zabawa w fingowaną bijatykę w błocie przed uszczęśliwioną publicznością, ale prawdziwa sportowa walka - tyle, że wszystkie chwyty dozwolone. [AS, 01, 43, 20]

Samochód postrzegany jako drapieżnik jest przedstawiony dość sugestywnie, choć niezbornie pod względem semantycznym:

(23) Podobnie jak jego wspaniały imiennik, ten Jaguar ma napędzane wszystkie cztery łapy... to znaczy koła. [AS, $01,43,20]$ 
(24) Aby jednak móc się zbliżyć do potencjalnych ofiar, musi wystąpić tu w jak najbardziej bojowym rynsztunku: z 3-litrowym, 230-konnym silnikiem V6 i w wydaniu Sport. [AS, 01, 43, 20]

Opisywany w artykule Jaguar zdradza, zgodnie z dziennikarskim konceptem, wszystkie cechy kotów, czy raczej te cechy, które swoim pupilom przypisują zachwyceni właściciele jest więc leniwy (przykład 25), sprytny i zwinny (przykład 26), przynosi radość i zadowolenie (przykład 27):

(25) Przy wysokich obrotach silnik wydaje głos jak rozpieszczony kanapowy kot, którego za karę pozbawiono niezasłużonej jakąkolwiek aktywnością kolacji. Jasne, Jaguary to koty, które w dziewięciu na dziesięć przypadków służą tylko do prężenia mięśni w „paradach atletów” po wielkomiejskim bulwarze. [AS, 01, $43,22]$

(26) A na okrasę mamy tu niesamowicie wręcz dobrą trakcję i szokująco niewymuszoną, elegancką, rzec by się od razu chciało: kocią zwinność. [AS, 01, 43, 22]

(27) A silnik mruczy w tonacji tak miłej wielbicielom tych jedynych w swoim rodzaju zwierząt - i samochodów, ma się rozumieć. [AS, 01, 43, 22]

Samochód kojarzony ze sportowcem (chodzi o Audi) zyskuje wstępnie etykietkę czempiona wieloboisty [AS, 01, 43, 20], a w dalszej części artykułu jest przedstawiany w następującym fachowym, ale też sugestywnym i hiperbolicznym opisie:

(28) Jego 3-litrowy, widlasty silnik sześciocylindrowy z kanałami dolotowymi o zmiennej długości zachowuje się jak atleta w siłowni - i to takiej nie do końca „czystej”, pompującej anabolikami. Nie wstydzi się swoich mięśni; z obu rur wydechowych dobiega tchnące siłą dudnienie. Ten brutalny, surowy niczym półdziki mocarz silnik nigdy nie jest $\mathrm{w}$ stanie nawet zbliżyć się do kultury pracy rycerskiego siłacza $\mathrm{z}$ Monachium, za to pod względem temperamentu i agresywności nie ustępuje mu ani na milimetr. [AS, 01, 43, 21]

\section{Wnioski}

Przedstawione w artykule zabiegi stylizatorskie sprawiają, że publicysta - autor tekstów publikowanych w prasie wyspecjalizowanej jawi się jako nadawca zaangażowany, budujący z odbiorcą wspólny świat i kształtujący określoną wizję tego świata:

- z punktu widzenia odbiorcy - z uwzględnieniem jego potocznych wyobrażeń i 


\section{doświadczeń;}

- zgodnie z oczekiwaniami odbiorcy, a więc przystępnie, plastycznie i sugestywnie;

- $\quad$ z (fingowanym) udziałem odbiorcy (por. różnorodne formy i przejawy dialogowości);

- za pomocą środków językowych znanych odbiorcy (potocznych) lub środków wykreowanych przy użyciu technik stylizatorskich typowych dla wypowiedzi potocznych.

Eksponowanie kontrastów ma służyć uwyraźnieniu tekstu, nadaniu mu kształtu przekazu gorącego, aktywizującego czytelnika. Wykształciły się przy tym dwie tendencje w komponowaniu wypowiedzi, odróżniające teksty informacyjne z prasy wyspecjalizowanej od tekstów z prasy ogólnej. Wzmianki, notatki, a także bardziej obszerne artykuły są kształtowane jako wypowiedzi, które mają powiadamiać i zarazem oceniać oraz oddziaływać. Środki stylistyczne o zróżnicowanej genezie (oficjalne, fachowe, potoczne z rejestru neutralnego lub emocjonalnego) przeplatają się $\mathrm{w}$ nich $\mathrm{w}$ obrębie podzielonego na akapity korpusu lub stanowią dominantę stylistyczną usamodzielnionych segmentów, tworzących strukturę mozaikową. Publicystyczne wyspecjalizowanie (publicystyczna fachowość) przybiera kształt fachowości upotocznionej. Świat dostępny specjalistom zyskuje wymiary świata przystępnego, otwartego dla niespecjalistów.

W prasie młodzieżowej lub kobiecej wysiłek stylizatorski publicystów zmierza do tego, aby w upotocznionym przekazie zawrzeć obraz rzeczywistości oczekiwanej, świata bardziej atrakcyjnego i doskonalszego od zwykłej codzienności.

Poszerza się zakres interferencji gatunkowych, obejmujących gatunki literackie i użytkowe (w tym wiele gatunków publicystycznych). Niektóre stylistyczne adaptacje są jednak dość ryzykowne. Ich rezultatami mogą być wypowiedzi ocierające się o kicz stylistyczny i językowy.

Analizy pokazują, że styl potoczny staje się dla dziennikarzy atrakcyjnym rezerwuarem zarówno środków, jak i technik stylizowania wypowiedzi. Interferencje stylów przyczyniają się do ich znaczących przeobrażeń. W upotocznionym stylu publicystycznym zmienia się hierarchia cech - status cech prymarnych zyskują obrazowość i dialogowość - a także wzbogaca zasób środków. Styl potoczny zaś zyskuje nowe środki wykreowane i upowszechnione przez prasę lub inne media, a ponadto doskonali się komunikacyjnie, zyskując coraz większy prestiż.

\section{Źródlo}


Powyższy tekst po raz pierwszy ukazał się w roku 2002 w tomie Nowe oblicza komunikacji we współczesnej polszczyźnie pod redakcją Grzegorza Szpili, Język a komunikacja 4 (tom 1): Kraków: Tertium; 323-334.

\section{Przypisy}

${ }^{1}$ Lubaś (2000a: 88) wskazuje liczne przyczyny wewnątrzsystemowe.

${ }^{2}$ Ze stanu badań wynika, że styl publicystyczny wyróżnia się szeregiem sprzecznych cech (co jest typowe dla stylów otwartych). Można w nim dostrzec zarówno wyznaczniki oficjalności, jak i spontaniczności, konkretność obok abstrakcyjności, obrazowość i ekspresywność obok zneutralizowanego i stonowanego sposobu wysłowienia (zob. Szczurek 1995: 377-378 i zawarte w tym opracowaniu wskazówki bibliograficzne).

${ }^{3}$ Lokalizując cytat podaję skrót tytułu pisma, rok wydania, numer i stronę.

${ }^{4}$ Analogiczne formy dialogowości pojawiają się w poradnikach zob. Wojtak (1994: 305).

${ }^{5} \mathrm{O}$ typach wzorców gatunkowych w odniesieniu do wypowiedzi dziennikarskich zob. Wojtak (2000b: 238239).

${ }^{6}$ Jest to forma narracji zakodowanej w pierwszej osobie. Monolog taki jest wyraźnie adresowany do milczącego słuchacza i uwzględnia jego reakcje. O zastosowaniu tej formy wypowiedzi w prasie zob. Wojtak (2000a: 119).

\section{Bibliografia}

Anusiewicz, Janusz (1992) „Potoczność jako sposób doświadczania świata i jako postawa wobec świata". [W:] Janusz Anusiewicz, Franciszek Nieckula (red.) Język a kultura, t. 5. Potoczność w języku i kulturze. Wrocław: Wydawnictwo Wiedza o Kulturze; 9-20.

Bartmiński, Jerzy (1992) „Styl potoczny”. [W:] Janusz Anusiewicz, Franciszek Nieckula (red.) Język a kultura, t. 5. Potoczność w języku i kulturze. Wrocław: Wydawnictwo Wiedza o Kulturze; 37-54.

Bartmiński, Jerzy (2001) „Styl potoczny”. [W:] Jerzy Bartmiński (red.) Współczesny język polski. Lublin: Wydawnictwo UMCS; 115-134.

Dunaj, Bogusław, Renata Przybylska, Kazimierz Sikora (1999) „Język na co dzień”. [W:] Walery Pisarek (red.) Polszczyzna 2000. Orędzie o stanie języka na przełomie tysiącleci. Kraków: Ośrodek Badań Prasoznawczych UJ; 227-251.

Kajtoch, Wojciech (1999) „Odlotowe bez dwóch zdań! Kultura języka, stylu perswazji w czasopismach dla młodzieży”. Zeszyty Prasoznawcze 3-4; 79-101.

Kamińska-Szmaj, Irena (2001) Słowa na wolności. Wrocław: Wydawnictwo Europa. 
Kita, Małgorzata (1993) „Perswazyjne użycie języka potocznego w kontakcie ogólnym”. [W:] Jacek Warchala, Aleksander Wilkoń (red.) Z problemów współczesnego języka polskiego. Katowice: Wydawnictwo Uniwersytetu Śląskiego; 33-41.

Lubaś, Władysław (1983) „Istota potoczności”. Biuletyn Polskiego Towarzystwa Językoznawczego XL; 85-90.

Lubaś, Władysław (2000a) „Słownictwo potoczne w mediach”. [W:] Jerzy Bralczyk, Katarzyna Mosiołek-Kłosińska (red.) Język mediów masowych. Warszawa: Upowszechnianie Nauki Oświata "UN-O"; 83-95.

Lubaś, Władysław (2000b) „O powstającym słowniku potocyzmów”. Język Polski 3-4; 161175.

Ożóg, Kazimierz (2001) Polszczyzna przełomu XX i XXI wieku. Wybrane zagadnienia, Rzeszów: Stowarzyszenie Literacko-Artystyczne "Fraza".

Skawiński, Jacek (1992) „Polszczyzna potoczna w funkcji interdialektu”. [W:] Janusz Anusiewicz, Franciszek Nieckula (red.) Język a kultura, t. 5. Potoczność w języku i kulturze. Wrocław: Wydawnictwo Wiedza o Kulturze; 81-86.

Szczurek, Ewa (1995) „Styl publicystyczny”. [W:] Stanisław Gajda (red.) Przewodnik po stylistyce polskiej. Opole: Wydawnictwo Uniwersytetu Opolskiego; 363-396.

Wojtak, Maria (1994) „Przyjacielsko, miło, zrozumiale, czyli o stylu poradnika”. [W:] Stanisław Gajda (red.) Kształcenie porozumiewania się. Opole: Wydawnictwo Uniwersytetu Opolskiego; 301-307.

Wojtak, Maria (2000a) „Wysoki współczynnik czadu, czyli o słownictwie w prasie specjalistycznej - na wybranych przykładach”. [W:] Jan Mazur (red.) Stownictwo współczesnej polszczyzny w okresie przemian. Lublin: Wydawnictwo Uniwersytetu Marii Curie-Skłodowskiej; 117-130.

Wojtak, Maria (2000b) „O przemianach w języku mediów (prasa wyspecjalizowana)”. [W:] Grzegorz Szpila (red.) Język a komunikacja 1. Zbiór referatów z konferencji „Język trzeciego tysiąclecia”. Kraków 2-4 marca 2000. Kraków: Tertium; 235-244.

Wojtak, Maria (2001) „Felietonowe gry ze stereotypem, czyli portret Polaka kierowcy”. Prace Filologiczne 46; 649-653.

Wojtak, Maria (2002) „O doskonałości wypowiedzi publicystycznej na przykładzie felietonów Joanny Szczepkowskiej”, [w:] Agnieszka Maliszewska (red.) O doskonałości, Łódź: Archidiecezjalne Wydawnictwo Łódzkie; 377-392.

\section{Wykaz stosowanych skrótów:}


P - „Przyjaciółka”

AS - „Auto Świat” 